\title{
Uluslararası Denetim Standartları Açısından Kurumsal Yönetim Sürecinin Değerlendirilmesi
}

\author{
Hasan TÜREDİ * \\ Tolga ALA** \\ Şükrü Mete TEPEGÖZ ${ }^{* * *}$
}

\section{ÖZET}

Günümüzde, sağlıklı mali yapı oluşturulması konusu tüm devletlerin ve uluslararası ekonomik örgütlerin en önemli çabalarından bir tanesidir. Bu sürecin doğmasına neden olan etkenler; sık karşılaşılan hileli işlemler veya hatalardan kaynakl şirket iflasları ve mali krizlerdir. İşletmeler sadece hâkim ortakların serbest yönetimine birakılmak istenmemektedir. Çünkü menfaat sahipleri olarak adlandirllan küçük pay sahipleri, devlet, kreditörler, çalışanlar için de işletmelerin sağlıklı yönetilmesi gerekmektedir. İşletmelerin sürekliliği önem kazanmıştır. Uluslararası Denetim ve Güvence Standartları Kurulu (International Auditing and Assurance Standards Board - IAASB) tarafindan yayınlanan Uluslararası Denetim Standartları (UDS) işletmelerin nasıl yönetilmesi konusuna vurgu yapmaktadır. Amaç, hesap verebilir, sorumlu, şeffaf, adil yönetilen işletmelerin oluşturulmasıdır. Bu işletmelerin sağlıklı yönetilmesinden başta yönetim kurulu olmak üzere tüm örgüt sorumludur. Kurumsal yönetim, işletmede yürütülen faaliyetlerde tüm paydaşların haklarının korunması bakımından yönetimin sorumluluklarını belirleyen bir çerçeve çizer. Bu çalışmanın amacı, kurumsal yönetim ile bă̆ımsız denetim standartları arasındaki ilişkiyi değerlendirmektir. Kontrol.

Anahtar Kelimeler: Kurumsal Yönetim, Uluslararası Denetim Standartları, UDS, Denetim Komitesi, Iç

JEL Sinıflandırması: M19, M42. \section{Standards}

ABSTRACT

Today, the issue of forming a sound financial structure is one of the most important efforts of all governments and international economic organizations. The causes of this process are; financial crises and corporate bankruptcies resulting from frequent fraudulent transactions or errors. The businesses are not only left to the free management of the controlling shareholder. Because small shareholders, which are called beneficiaries, the state, the creditors and the employees, the businesses need to be managed well. Going concern concept has gained importance. The International Auditing Standards issued by the International Auditing and Assurance Standards Board emphasize how to manage businesses. The aim is to create accountable, responsible, transparent, fairly managed businesses. The whole organization, especially the board of directors, is responsible for the good management of these businesses. Corporate governance have form a frame for border defining the responsibilities of management in terms of protecting the rights of all stakeholders in business activities. The purpose of this study is to assess the relationship between corporate governance and independent audit standards. Control.

Keywords: Corporate Govarnance, International Audting Standarts, IAS, Audit Committee, Internal

Jel Classification: M19, M42.

\footnotetext{
* Prof. Dr. Hasan Türedi, İstanbul Ticaret Üniversitesi, İşletme Fakültesi, hturedi@ticaret.edu.tr ** Öğr. Gör. Tolga Ala, Erzincan Üniversitesi, Tercan Meslek Yüksekokulu, tala@erzincan.edu.tr

*** Şükrü Mete Tepegöz Serbest Muhasebeci Mali Müşavir, Bağımsız Denetçi, Finansbank İstoç Şube Müdürü, sukrumete.tepegoz@finansbank.com.tr
} 


\section{GİRIŞ}

İşletmeler büyüdükçe yapılan işlemlerin çeşitliliği ve hacmi artmaktadır. İşletmeler arası rekabet; işletmeleri daha planlı ve kontrollü olmaya zorlamaktadır. İşletme faaliyetleri yerine getirilirken, hızlı, yoğun ve karmaşık olarak yürütülen faaliyetlerde çeşitli aksaklıklar olabilmektedir. Muhtemel aksaklıklar ve düzensizlikler işletmelerde hile ve suiistimal ortamlarının oluşmasına imkân vermektedir.

Son yüzyılda işletme faaliyetlerinin çeşitlenmesi ve genişlemesinden kaynaklanan eksiklik ve aksaklıkların da etkisiyle, şirketlerde muhasebe ve denetim hileleri sayısında artışlar gözlemlenmiş ve doğru olmayan bu tür mali bilgiler tüm tarafları önemli ölçüde zarara uğratmıştır. Yaşanan bu gelişmeler piyasaları da ciddi düzeyde tedirgin etmiş, mali bunalımlara neden olmuştur.

Kurumsal yönetim, her türlü hatalı veya hileli uygulamaya karşı her düzeyde yapılması gereken en alt düzeydeki standartları düzenler. Kurumsal yönetim uygulamaları işletmelerin yönetim yapılarında ciddi değişiklikler meydana getirmektedir. Bu değişikliklerin etkili olduğu alanların başında muhasebe ve denetim gelmektedir.

\section{KURUMSAL YÖNETIMIIN KAVRAMSAL YAPISI}

İktisadi yaşamın sürekliliği için fayda ve değer üreten işletmelerin yaşamlarının sağlıklı ve uzun olması gereklidir. İşletmeler, iktisadi yaşamın temel yapı taşlarıdır. Ancak, başta gelişmiş ülkelerde yer alan çok uluslu işletmeler olmak üzere hile ve/veya hatalı uygulamalar nedeniyle sıklıkla şirket iflasları görülmektedir. Oysa işletme faaliyetlerinin sürekli olması genel iktisadi yapıyı ve işletmeden fayda sağlayan yatırımcıları, çalışanları, borç verenleri, müşterileri, kamu idaresi olarak çıkar sağlayan grupları doğrudan ilgilendiren bir konudur.

İktisadi sistemin bir görevi de, insan kaynakları ve doğal kaynakların etkin ve verimli bir biçimde kullanılması yoluyla nitelik artışı, çevrenin korunması vb. sosyal sorumlulukları yerine getirerek sosyal refaha katkıda bulunmaktır.

\subsection{Kurumsal Yönetim Kavramı}

Ekonomik İş Birliği ve Kalkınma Örgütü (OECD) ülkeleri arasında 14 Aralık 1960 tarihinde, imzalanan konvansiyonda özetle; üye ülkelerde mali istikrarın korunması, iktisadi büyüme ve istihdamın sürdürülebilir seviyelerde gerçekleşmesi ve yaşam standardının yükseltilmesi konularının destekleneceği belirtilmektedir. Bunun gerçekleşmesini sağlayacak en önemli unsurlar özel işletmelerdir. Özel işletmelerin de sermayelerinin doğru ve verimli yönetilmesi ihtiyacı kaçınılmazdır. Bu kapsamda, OECD Bakanlar Kurulu, 1998’de OECD'den bir dizi standart ve yol gösterici ilke geliştirmesini talep etmişstir. Kurumsal Yönetim İlkeleri bu talebe cevap vermektedir.

Türkiye'de "Corporate Governance" kavramının karşılığı olarak "kurumsal yönetim" ve/veya "yönetişim" kavramları kullanılmaktadır (Koçel, 2003: 468). Kurumsal yönetim, kurumsallaşma ve kurumsal kültür kavramları anlam düzeyleri bakımından çok farklı olmalarına rağmen özen gösterilmeden birbirlerinin yerine kullanıldıkları görülmektedir. 
Bir kesimin deyişiyle "kurumsal yönetişim”, yasal düzenleme ayağında egemen rol üstlenen Sermaye Piyasası Kurulu ve onu izleyenlerin "kurumsal yönetim" terimi ile olarak ifade ettiği bu önemli kavram, şirketlerin/kurumların yönetildiği ve kontrol edildiği bir sistemi ifade etmektedir. Dar anlamı ile kurumsal yönetim, şirketlerde öncelikle pay sahiplerine dayalı hakların gözetilerek yönetilmesidir. Bu bağlamda sorumlu organ yönetim kuruludur. Oysa bu kavram, geniş anlamda bir şirketin pay sahipleri, yönetim kurulu ve üst yönetimi arasındaki ilişkileri kapsamaktadır. Bu ilişkiler, kurumsal amaçların belirlendiği ve başarının izlendiği bir çerçeveyi belirlemektedir. Kurumsal başarının anahtarı sayılan üç kesimden birisi, bilindiği gibi yönetim kurulunu seçen pay sahipleridir. İkinci önemli unsur yönetim kuruludur. Üçüncüsü ise, murahhas yönetici ve onun yön verdiği üst yönetim kademesidir (Gürbüz, 2005: 1).

Ekonomik İşbirliği ve Kalkınma Örgütü (OECD) Kurumsal Yönetim Komitesi’ne göre; kurumsal yönetim hem iktisadi verimlilik ve büyümeye ilişkin iyileştirilmenin hem de yatırımcı güveninin artırılmasının bir unsuru olmakla birlikle, bir şirketin yönetiminde yönetim kurulu, hissedarları ve diğer paydaşlar, ilişkili olanlar arasındaki bir dizi ilişkiler bütünüdür (OECD, 2004).

Başka bir anlatımla, kurumsal yönetim; işletme ya da şirkette yürütülen tüm faaliyetlerde doğrudan ya da dolaylı olarak bütün paydaşların haklarının korunması bakımından yönetimin sorumluluklarını gösteren bir yönetim şeklidir (Aktan, 2006: 150).

İyi kurumsal yönetimin kendisi bir amaç değildir. Uzun dönemli yatırım için öz sermayeye erişime ihtiyaç duyan şirketler için gerekli olan piyasa güveninin ve iş dürüstlüğünün yaratılması için bir araçtır. Özsermayeye erişim özellikle geleceğe yönelik büyüyen şirketler ve artan borçluluğu dengelemek için önem arz etmektedir (OECD,2015).

Kurumsallaşma işletme sahipleri ve yöneticileri açısından bakıldığında, bir şirketin, kişilerden bağımsız kuralların ve standartların bulunduğu, sürekli değişen çevre koşullarını takip eden bir yapıda, sürekli gelișen bir kurum yapısının var olması; kendisine özgü uygulama neticesini, iş yapma usul ve yöntemlerini iç kültürü haline getirmesi ve bu bağlamda diğer şirketlerden farklı ve ayırt edici bir kimliğe bürünmesi sürecidir, şeklinde ifade edilebilir (Karpuzoğlu, 2004: 72).

Kurumsal yönetim, aynı zamanda şirketin hedeflerinin belirlenmesi ve buna mukabil etkinlik ve verimliliğinin bu hedeflere ulaşma ve izleme araçlarının belirlenmesine yönelik bir yapı sağlamaktadır. Şirketin iç denetim sistemleri ve yönetim kademesi kurumsal yönetimin inceleme konularından sadece bazılarıdır (OECD, 2004).

Kurumsal yönetim, işletmenin üst yönetiminin denetimi, yönlendirilmesi ve işletme üzerinde hak iddia eden diğer paydaşların (çalışanlar, müşteriler, alacaklılar, fon sağlayanlar ve devlet gibi) üst yönetimle olan ilişkilerinin bütününü kapsar (Koçel, 2003: 469).

\subsection{Kurumsal Yönetim Anlayışı ve İlkeleri}

Kurumsal yönetimin, ortak bir anlayışa sahip olabilmesi için şeffaflık (transparency), hesap verebilirlik (accountability), sorumluluk (responsibility) ve adillik (fairness) temel ilkeler olarak tüm dünyada kabul edilmiştir (Zehnder, 2000: 3). 
Kurumsal Yönetim Merkezinin (Corporate Governance Center) yayınladığ 1 “ABD Halka Açık Şirketleri için 21. Yüzyıl Yönetim İlkeleri” adlı raporunda 10 adet yönetim ilkesi belirleyip, tavsiye etmiştir (Asian Passific Economic Corporation Forum, 2003: 5).

Bu ilkeler şunlardır:

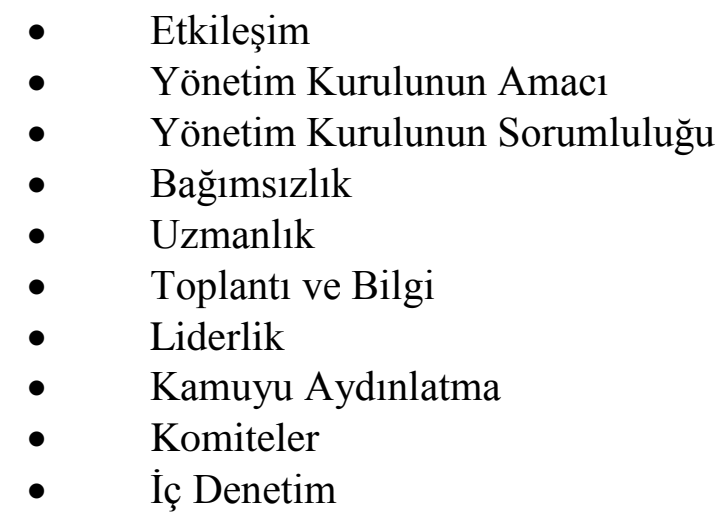

Kurumsal yönetim ilkeleri sayısında son yıllarda artış olduğu ve sürekli geliştiği gözlemlenmektedir. İlkeler, aslında kurum yapısı ile çalışanların nitelikli uyumunu amaçlayan iyileştirmeler bütünüdür. Kurumsal yönetim ilke çerçevesine ek olarak kurumsal yönetim anlayışının geliştirilmesinde düzenleyici kurumlar da önemli rol oynamaktadır. Çünkü kurumsal kültürün yerleşmesinde düzenleyici kurumlar ile düzenleyici ortam önemli bir etkendir. Bulunduğu ülkenin şartları, genel iktisadi ve hukuki yapısı ile uygunluk etkin kurumsal yönetim anlayışını geliştirici etkenler arasındadır.

Yönetim kurulları, hissedarları ve doğrudan çıkar sahibi diğer paydaşlar arasındaki bir dizi ilişki ağının uyum başarısı iktisadi verimliliği artırmanın temel unsurları arasında sayılabilir (OECD, 1999: 11). Şeffaflığın ve kontrol edilebilirliğin geliştirilmesi iş dünyasının tümünü ilgilendirdiğinden sayılan bu etkenler kurumsal yönetim anlayışında en temel noktalardır (Emerging Markets Committee, 1998).

OECD tarafından 1999 yılında geliştirilmiş olan "Kurumsal Yönetim İlkeleri” daha sonra gözden geçirilerek 2004 yılında güncellenmiştir. Bu süreç tüm OECD üyesi ülkelerinin eşit düzeyli bir katılımıyla OECD Kurumsal Yönetim Komitesi himayesinde gerçekleştirilmiştir.

Dünya'nın çeşitli bölgelerinde ve ülkelerinde düzenlenen Bölgesel Kurumsal Yönetim Yuvarlak Masa Toplantıları'nın, pek çok katılımıının gözden geçirme çalışmasına katkısı önemli ölçüde dikkate alınarak uzmanlar danışma toplantısı yapılmış ve internet üzerinden kamuoyu görüşüne sunularak diğer paydaş ve uygulayıcıların katkısı sağlanmıştır. 2015 yılı başlarında İstanbul'da gerçekleşen G20 Bakanlar ve Merkez Bankası Başkanları toplantılarında ilkeler tekrar gözden geçirilmiştir. İlkeler, en son olarak G20 Yatırım ve Altyapı Çalışma Grubu (IIWG)'nun Mayıs ve Ağustos 2015 toplantılarına sunulmuştur. Konsey tarafından Kurumsal Yönetim İlkeleri kabul edilmiş ve Kasım 2015'teki G20 Liderler Zirvesinde son şeklini almıştır. Kurumsal yönetim ilkelerinin güncelleştirilmiş son hali şöyledir: 
$\checkmark \quad$ Etkin kurumsal yönetim çerçevesinin temelinin sağlanması,

$\checkmark \quad$ Pay sahiplerinin hakları ve adil muamele görmeleri ile temel ortaklık işlevleri,

$\checkmark \quad$ Kurumsal yatırımcılar, pay senedi piyasaları ve diğer aracılar,

$\checkmark \quad$ Menfaat sahiplerinin rolü,

$\checkmark \quad$ Kamuyu aydınlatma ve şeffaflık,

$\checkmark \quad$ Yönetim kurulunun sorumlulukları.

\subsection{Denetim Komitesi}

Denetim komitelerinin, kurumların tüm yönetim kademelerinde üst yönetim ve yönetim kurulu adına gözetim faaliyetinin yürütülmesinde önemli görevleri bulunmaktadır. Denetim komiteleri işletmelerdeki konumu ve üstünlük (inisiyatif) alanları itibariyle iç denetim faaliyetlerinin koordinasyonuna referans teşkil edecek görevler üstlenmektedir. Denetim komiteleri kurumsal yönetim faaliyetlerinin tesisi ve kurum içi oryantasyon ve uyum süreçlerinde üstlendiği görevler nedeniyle bahsetmekte yarar bulunmaktadır. Kurumsal yönetim ilkelerinin tüm yönetim süreçlerinde izlenmesi için denetim komiteleri ve benzer organlara ihtiyaç duyulmaktadır.

İlkeler, kurumsal yönetim politikalarının; yatırımcı güveni, sermayenin oluşumu ve tahsisi konularında daha kapsamlı iktisadi amaçları başarmada önemli bir role sahip oldukları anlayışıyla geliştirilmiştir. İyi kurumsal yönetimin tek bir uygulama modeli yoktur. Öte yandan, iyi kurumsal yönetimi oluşturan birtakım ortak unsurlar bulunmaktadır. İlkeler, bu ortak unsurların üzerine kurulmuştur ve mevcut farklı modelleri bünyesinde barındıracak şekilde tasarlanmıştır. Örneğin, İlkeler, belirli bir yönetim kurulu yapısını önermemektedir ve aynı zamanda ilkelerde kullanılan "yönetim kurulu" terimi farklı ulusal modellerdeki yönetim kurulu yapılarını içinde barındırmaktadır (G20/OECD Kurumsal yönetim ilkeleri, 2015).

Denetim komitesi, kurumsal yönetim sistemi içerisinde önemli bir role sahiptir. Komite, şirket içerisinde kaliteli ve güvenilir mali raporlama ve kontrol yapılarının sağlanmasının yanı sıra risklerin tespiti ve yönetilmesinde de üst düzeyde bir öneme sahiptir (Hermanson, ve Rittenberg, 2003: 50).

Bazı durumlarda, işletmelerde denetim komiteleri (veya farklı olarak adlandırılmış benzer alt gruplar) bulunur. Bunların belirli yetki ve görevleri birbirinden farklılık gösterse bile, mevcut bir denetim komitesiyle kurulacak iletişim, denetçinin üst yönetimden sorumlu olanlarla kuracağı iletişimde kilit bir unsurdur. İyi yönetim ilkeleri: (260/Bağımsız Denetim Standartları A7)

Yine aynı standardın devamında denetçi ile denetim komitesinin kuracağ iletişimin düzeyi önem arz etmektedir. Denetçi ile denetim komitesinin sürdüreceği ilişkinin başarısı denetim sürecini olumlu etkileyeceği düşünüldüğünden ilgili standartta aşağıdaki bazı önemli hususlara işaret etmektedir:

- Denetçinin denetim komitesi toplantılarına düzenli olarak davet edilmesini,

- Denetim komitesi başkanının ve ilgili durumlarda denetim komitesinin diğer üyelerinin düzenli aralıklarla denetçiyle iletişim kurmasını,

- $\quad$ Denetim komitesinin, yılda en az bir defa yönetimin bulunmadığı bir ortamda denetçiyle görüşmesini tavsiye etmektedir. 
Denetimden sorumlu komite ya da meslek ahlâkı komitesi veya eşdeğer bir organ, şirketin mali tablolarının doğruluğu için ayrıca tehlike teşkil edebilecek, ahlaki ya da yasal olmayan davranışlara ilişkin endişelerini ihbar etmek isteyen çalışanlara bir iletişim noktası sunmalidir.

$\mathrm{Bu}$ iddiamıza benzer bir görüş Bağımsız Denetim Standartlarında karşımıza çıkmaktadır. İlgili standartta: Muhtemel çıkar çatışmaları veya görünüşte kalan çıkar çatışmalarını içeren ilişkili taraf işlemlerinin onaylanmasına yönelik açık bir rehberin bulunması gerektiği özellikle vurgulanmıştır. Örneğin, bu tür işlemlerin yönetimden bağımsız olan ve üst yönetimden sorumlu olanlar arasından seçilen üyelerden oluşan bir alt komite tarafından onaylanmasını tavsiye etmektedir. (550/Bağımsız Denetim Standardı, A/17 md.5)

Kurumsallaşma sürecinin en temel öğesi insan kaynaklarıdır. Niteliksiz insan kaynaklarıyla kurumsallaşma çalışmalarına yürütmek ve bir netice almak zor olduğu kadar külfetli bir meseledir. Aynı zamanda tüm işletme yapısı tarafindan kurumsallaşma düşüncesini benimsenmesi, desteklenmesi ve sonraki kuşaklara aktarılması yönünde gerekli eğitim çalışmalarının başlatılması gerekmektedir (Ulukan, 2005: 29-42).

İşletmelerde yönetim kurullarının en önemli görevlerinin arasında, kurumun gelecekte karşılaşabileceği önemli risklerin belirlenmesi, bu risklerin kontrolü ve etkili bir şekilde karşılanmasını sağlayıcı yönetim tedbirlerini almak yer alır. Kurumun hesap verebilir yapıda olabilmesi için, kamuoyuna açıklayacağı bilgilerin şeffaf, doğru ve zamanında paylaşılması da yönetim kurulunun görev ve sorumlulukları arasındadır. $\mathrm{Bu}$ nedenle yönetim kurulları kendi içinden bağımsız bir denetim komitesi belirleyerek bu konuların daha da ayrıntılı olarak ele alınmasını sağlamaya çalışır. Denetim komitelerinin yapısı, üye sayısı gereksinimler ihtiyaçlar nispetince işletmeden işletmeye değişebilir. Önemli olan üye sayılarının çokluğu değil, bağımsızlığıdır.

2006 yılında yapılan düzenlemeler neticesinde; Sermaye Piyasası Kurulu (SPK) ve Bankacılık Düzenleme ve Denetleme Kurumu (BDDK) tarafindan yapılan düzenlemelerle denetim komitesi uygulaması başlatılmıştır. Bankacılık düzenlemeleri ve SPK bağımsız denetçinin seçiminden ve bağımsız denetimin gözetimine kadar denetim komitesinin görev ve sorumluluklarını açıklamıştır. 6102 sayılı Türk Ticaret Kanunu'nda ise denetim süreçlerinde öngörülen kurul ve kurumların tam olarak denetim komitesiyle bir ilişkisi yoktur. Denetim faaliyetlerinin yürütülmesinde dürüst resim ilkesi ve denetim standartlarına yer yer atıflarda bulunulmuştur.

Şirketin büyüklügü ve yönetim kurulunca uygun görülmesi durumunda, komitelerin işlevlerinin belirlenmesi yönetim kurulunun çalışmasını geliştirebilir. Piyasanın yönetim kurulu komitelerinin başarısını değerlendirmek için bu komitelerin amaç, görev ve oluşumları hakkında tam ve net bilgilere sahibi olması gerekmektedir. Söz konusu bilgiler, yönetim kurullarının, bağımsız denetçilerle olan ilişkilerini gözetleme ve çoğu zaman bağımsız olarak hareket etme yetkisine sahip, denetimden sorumlu komitelerin kurduğu yargı çevrelerinde özellikle önem arz etmektedir. Denetimden sorumlu komiteler ayrıca iç kontrol yapılarının etkinliğini ve doğruluğunu denetleyebilmelidir (G20/OECD Kurumsal yönetim ilkeleri, 2015). 
6102 sayılı Türk Ticaret Kanunu 366/2 maddesine göre; yönetim kurulu, işlerin gidişatını izlemek, kendisine sunulacak konularda rapor hazırlamak, kararlarını uygulatmak veya iç denetim amaciyla içlerinde yönetim kurulu üyelerinin de bulunabileceği komiteler ve komisyonlar kurabilir.

Denetim komitesi esasında işletmenin menfaatleri ile pay ve menfaat sahiplerinin hak ve çıkarlarının gözetilmesinde denge rolü üstlenmektedir. İşletmelerin orta yönetim kademeleri (birim/departman yöneticileri, müdürler, birimlerin alt faaliyet şefleri) genelde icradan sorumlu iken üst yönetimler daha çok icraatın gözetiminden sorumludur.

Denetim komiteleri iç denetim faaliyetlerinin daha etkin ve verimli gerçekleştirilmesinde önemli görevler yerine getirmektedir. İç denetim faaliyeti temelde üç farklı denetimi içerir. Bunlar mali denetim, uygunluk denetimi ve faaliyet denetimidir. Denetim komiteleri sayesinde yönetim kurulları kurumsal yönetim ilkeleri çerçevesinde mesleki bir yaklaşım içerisinde çalışma etkinliğine erişebilirler. Denetim komitesinin oluşturulmasında teşkilatlanma yapısı ile sorumluluklarının dağılım planının göz önünde bulundurulması gerekir.

İç denetim faaliyetlerinin oluşturacağı katma değer, risklerin ve risk değerleme süreçlerinin anlaşılabilirlik düzeyine katkı sağlar. Kurum faaliyetleri üzerinde makul güvenceyi iyileştirir.

\section{ULUSLARARASI DENETIMM STANDARTLARI VE KURUMSAL YÖNETIM İLIŞKISİ}

Denetim kavramları komitesine1 göre muhasebe denetimi; "İktisadi faaliyet ve olaylarla ilgili iddiaların önceden saptanmış ölçütlere uygunluk derecesini araştırmak ve sonuçlara ilgi duyanlara bildirmek amacıyla tarafsızca kanıt toplayan ve bu kanıtları değerleyen sistematik bir süreçtir” (Güredin, 2010:11).

Denetim faaliyeti önceden belirlenmiş ölçütler bağlamında, bağımsız kişiler tarafindan bilgilerin uygunluk derecesinin belirlenerek makul bir düzeyde değerlendirilerek doğrulanmasını amaçlayan, açıklayıcı ve bilgi verici raporlamaları kapsayan sorgulama dizisidir.

Uluslararası denetim standartları, denetim faaliyetinin mesleki deneyim ve eğitime sahip kişiler tarafından tüm süreçlerinde mesleki özen ve bağımsız bir şekilde yürütülmesini öngörmektedir.

Uluslararas1 Muhasebeciler Federasyonu (International Federation of Accountants IFAC) bünyesinde kurulan Uluslararası Denetim ve Güvence Standartları Kurulu (International Auditing and Assurance Standards Board - IAASB) tarafindan yayınlanmakta olan Uluslararası Denetim Standartları (UDS) Türkiye'de ulusal denetim standartları oluşturulurken Sermaye Piyasası Kurulu ve Bankacılık Düzenleme ve Denetleme Kurulu gibi birçok düzenleyici otorite tarafından örnek alınmıştır (Şavlı, 2012: 2).

\footnotetext{
${ }^{1}$ 20.yüzyılın son çeyreğinde Amerikan Muhasebeciler Birliği bünyesinde kurulmuş, denetimi ilk defa sistematik bir süreç olarak kabul eden ve tanımlayan komitedir. (Committee on Basic Auditing Concepts)
} 
Genel Kabul Görmüş Denetim Standartlarının temel yapısı, genel standartlar, çalışma sahası standartları ve raporlama standartları olarak üç ana kısımdan oluşmaktadır. Söz konusu Standartların ilk kısmı genel standartlara ayrılmıştır. Bu standartlar denetçilerin nitelikleri, tutum ve davranışları, mesleki eğitimleri ile ilgili esasları içerir. $\mathrm{Bu}$ açıdan bu standartlara kişisel standartlar adı da verilmektedir.

1- Genel Standartlar

- Mesleki eğitim ve yeterlilik standard1,

- Bağımsızlık standardı.

- $\quad$ Mesleki özen ve titizlik standard1,

2- Çalışma Alanı Standartları

- $\quad$ Planlama ve gözetim standard1,

- İç kontrol sisteminin incelenmesi standard1,

- Yeterli kanit toplama standard,

- Çalışma kâğıtlarının hazırlanması standardı.

3- Raporlama Standartları

- $\quad$ Genel kabul görmüş muhasebe ilkelerine uygunluk.

- Muhasebe ilkelerinde tutarlılık standardı,

- Tam açıklama ilkesine uyum standard1,

- $\quad$ Görüş bildirme standard1.

100-700 numaralı gruplarda yer alan Bağımsız Denetim Standartları (BDS'ler) finansal tabloların denetiminde uygulanır. 700 ile 799 arasındaki standartlar denetim raporunun hazırlanmasına ilişkin hususları içermektedir.

\begin{tabular}{|c|c|c|}
\hline Genel İlke ve Sorumluluklar & Çalışma Alanı Standartları & Raporlama Standartları \\
\hline $200-299$ & $300-699$ & $700-799$ \\
\hline
\end{tabular}

Denetim standartları denetçiye mesleki sorumluluğunu yerine getirilmesinde ona yardımcı olan, ona denetim faaliyetlerinde 1şık tutan genel ilkelerdir. Yürütülen denetimin uygun ve geçerli kabul edilebilmesi için denetçinin bu ilkelerden hiçbir şekilde ayrılmaması gerekir” (Güredin, 2010: 39).

Muhasebe standartları ve denetim standartları finansal raporların hazırlanmasından sunumuna kadar geçen sürece yön veren, gerçeği yansıtıp yansıtmadıklarına dair tüm endişeleri en aza indirmeyi amaçlamaktadır.

\subsection{Kurumsal Yönetim Süreçlerinin Denetim Genel Standartlarıyla İlişkisi}

Denetim standartlarının yapısı incelendiğinde ilk olarak genel standartlar ile başladığı görülmektedir. Genel standartlar içerik olarak denetçiye ilişkin esas teşkil eden hususları 
açıklamaktadır. Denetçilerin sahip olması gereken nitelikler, davranışları ve mesleki eğitimlerini kapsamaktadır. Bu standartlara aynı zamanda kişisel standartlar adı da verilebilmektedir. Mesleki yeterlilik, bağımsızlık, mesleki özen ve titizlik olmak üzere üç başlık altında toplanan genel standartlar denetim standartlarının ana zeminini oluştururlar.

Uluslararası denetim standartları Kalite Kontrol Standardı ile başlayan genel standartlar kapsam ve uygulama alanı yönüyle ele alınmıştır. Denetim sürecini esas alan ana hükümler ve bunlara ilişkin tanımlamalar yer almaktadır.

Denetim faaliyeti sosyal bir olgu olduğu kadar teknik bir meseledir. Bu yüzden denetim faaliyetinin, alanında uzman kişilerce yapılması önem arz etmektedir. Denetim faaliyetinin planlanması ve yürütülmesinde çalışma alanı standartları ve raporlama standartlarının uygulanabilirlik kapasitesi genel standartların kabiliyeti ile doğru orantılıdır. Denetimin planlanması, programının oluşturulması denetçinin niteliği ile birebir ilişkilidir. İdeal denetçi esasen genel denetim standartları çerçevesinde çalışma alanı ve raporlama standartlarına da yön verebilme yetkinliğine sahiptir.

Denetim faaliyetlerinin kalitesi denetçinin niteliklerine bağlı olarak ölçülür. Denetçinin veya ilgili denetim biriminin denetim faaliyetini etkin yürütebilmesi bazı etkenlere bağlıdır. Bunların en önemlilerinden biri denetçinin sahip olması gereken mesleki şüphecilik düzeyidir. Mesleki şüphecilik denetimin en önemli öğelerindendir. Mesleki şüphecilik; denetim süresince denetçinin mesleki yargısına rehberlik eden, olası yanıltıcı ve hileli işlemlere karşı onu duyarlı kılan, bağımsızlığını pekiştiren eleştirel değerlendirmeler bütünüdür.

Standartlara bakıldığında görüleceği üzere mesleki şüphecilik kavramının içeriğine yönelik açıklayıcı ifadeler yer almaktadır. Denetim sürecinin başarıyla yürütülmesinde bir kontrol faktörü olduğu belirtilmiştir. Mesleki şüphecilik, elde edilen bilgilerin ve denetim kanıtlarının, hile kaynaklı önemli bir yanlışlık olabileceğine işaret edip etmediğinin sürekli olarak sorgulanmasını gerektirdiği üzerinde durulmuştur. Mesleki şüphecilik ile denetçinin denetim süreçlerinde denetim kanıtı olarak kullanılacak bilgilerin güvenilirliğinin ve uygun hâllerde bu bilgilerin hazırlanması ve muhafazasına ilişkin kontrollerin göz önünde bulundurulması beklenmektedir. (240/Bağımsız Denetim Standardı)

Bağımsız denetim standartlarının genel standartlar kısmında sayılan nitelikler mesleki şüphecilik kavramını vurgulamaktadır. Mesleki şüphecilik kavramının kurumlarda yansıması çok yönlü bir şekilde karşımıza çıkabilmektedir. Bağımsız denetçinin denetim sürecinde makul güvenceye ulaşabilmesinde mesleki şüphecilik önemli katkılar ve destekler sağlamaktadır. Denetim komitelerindeki mesleki şüphecilik olgusunun yansıması; risk yönetiminin daha etkin yürütebilmesine imkân sağlayabileceği gibi üst yönetimin gözetim kalitesini artırdığı da söylenebilir. Kurumsal bilginin daha iyi yönetilebilmesine öncelikli firsatlar sağlamakta ve rol almaktadır.

Kurumsal yönetim üst yönetim ve tüm paydaşlar arasında doğru, güvenilir bilgiye dayalı ilişki ağını kapsamaktadır. İhtiyaç duyulan doğru ve güvenilir bilginin nasıl sağlanacă̆ 1 kurumdan kuruma kapsam yönünden değişkenlik gösterebilir. Çünkü her kurumun iş ortamı, faaliyetleri, sektörü, işlem çeşitliliği, teşkilat yapısı birbirinden farklıdır. Kurumsal yönetim ilkeleri bu hususta yönetim mekanizmasının geliştirilmesine 
yönelik bir çerçeve oluşturma amacı taşırken, denetim faaliyetleri ise bir anlamda yönetim faaliyetlerinin türevi niteliğinde olup, makul güvence sağlayabilme amacı taşırlar. Kurumsal yönetimin sürdürülebilirliğine yönelik ciddi katkıları olduğunu ifade edebiliriz.

Kurumsal yönetimin en temel beklentileri arasında güvence mekanizmasının kurum içerisinde daimi suretle tesis edilmesi yer almaktadır. Kurumsal yönetim ilkelerinin tek başına bu beklentilere çözüm bulması yeterli değildir. Kurumsal yönetimin bir mekanizma halini alması, işler hale getirilmesi için kurumsal yönetim ilkeleri sşığında iç kontrol faaliyetleri ile desteklenmelidir. Böylelikle bağımsız denetimin ve iç kontrolün olgu tabanlı yürütülmesi bir anlamda önem arz etmektedir. Çünkü, denetim standartlarının ön gördüğü "mesleki şüphecilik" kavramını sadece denetim meslek mensuplarına ait bir mesleki argüman olmaktan çıkarıp, kişileştirilmekten uzak, tüm kurum temelinde yaygınlaştırılması gerekmektedir.

\subsection{Kurumsal Yönetim Süreçlerinin Çalışma Alanı Standartları ile İlişkisi}

Çalışma alanı standartları denetçiye güvenilir bir denetim görüşü için gerek duyulan işlemleri düzenleyen ve açıklayan standarttır. Denetim sürecinin planlanması aşamasından iç kontrol yapılarının yardımıyla bu kanıtların toplanması ve tekrardan gözden geçirilme aşamalarına ve kanıtların değerlendirilmesine kadar geçen süreçleri kapsamaktadır. Çalışma alanı standartları genel standartlara göre daha detaylı bir içeriktedir. Çalışma alanı standartlarının iyi uygulanması nitelikli bir denetim programının oluşturulmasına katkı sağlar. İyi oluşturulan denetim plan ve programı zaman israfının önlenmesi ve kaynakların verimli kullanılması gibi önemli etkiler sağlayabilir. Denetim süreçlerinde makul bir zaman planlaması yapılamadığı durumlarda suiistimal ve hileli durumların ortaya çıkartılması zorlaşmaktadır.

Genel olarak UDS'ler (Uluslararası Denetim Standartları) denetçinin genel amacına ulaşabilmesi için yapması gereken bütün faaliyetleri kapsadığından yönlendirici ve açıklayıcı bilgiler içermektedir. Birçok standart maddesinde en göze çarpan hususlar arasında küçük işletme ve büyük işletme ayırımı dikkat çekmektedir. Ayrıca denetim sürecinde denetçinin karşılaşabileceği özel durum ve buna özgü hususların altı özenle çizilmektedir.

Standartlarda küçük işletmelere özgü hususlar ayrı bir başlıkla ele alınmış olmakla birlikte bazı açıklamalara yer verilmiştir. Küçük işletmeler genellikle daha az çalışana sahiptir. $\mathrm{Bu}$ durum, görevler ayrılı̆̆ı ilkesinin uygulanabilirliğini sınırlandırabilir. Ancak küçük ve sahibi tarafından yönetilen bir işletmede işletme sahibi, büyük bir işletmeye göre daha etkin bir gözetim uygulayabilir. Yönetim tarafından gerçekleştirilen bu üst düzey gözetimin, yönetimin kontrolleri ihlâl etme ihtimalinin artmasına karşı dengelenmesi gerektiği belirtilmiştir (265/ Bağımsız Denetim Standardı).

Aynı zamanda küçük işletmelerde, denetçi tarafından belirlenebilecek çok sayıda kontrol faaliyeti olmayacağından bahsedilmiş ve kontrollerin mevcudiyetine veya işleyişine ilişkin işletme tarafından yapılan belgelendirmenin kapsamı sınırlı ve az olabileceğine değinilmiştir. $\mathrm{Bu}$ tür durumlarda denetçinin öncelikli olarak maddi doğrulama prosedürlerinden oluşan müteakip denetim prosedürlerini uygulaması daha etkili olabileceği önemle altı çizilmiştir. (265/ Bağımsız Denetim Standardı) 
$\mathrm{Bu}$ standartların bir önemli özelliği de denetçinin denetim işlemi sonucunda mesleki yargısına ulaşmasını etkileyecek faktör ve koşulların uygunluğunu düzenlemesidir. Denetimin amaçlarının sağlanıp sağlanamadığı denetçinin denetim sürecinde sergileyeceği sorumluluk düzeyi ile denetim sonucunda erişeceği mesleki yargısına bağlıdır. Yani denetimin etkinlik derecesine tesir eden hususlar çalışma alanına ilişkin standartlarda açıklanmıştır.

Standartlara göre; denetçinin amacı, denetim sırasında tespit ettiği ve mesleki muhakemesi sonucunda üst yönetimden sorumlu olanların ve yönetimin dikkatini çekmeyi gerektirecek kadar önemli olduğuna kanaat getirdiği iç kontrol eksikliklerini uygun bir biçimde üst yönetimden sorumlu olanlara ve yönetime bildirmek olduğu önemle belirtilmiştir. (265/ Bağımsız Denetim Standardı)

Yukarıda açıklanan standarttan anlaşıldığı üzere denetçinin hileye ilişkin bir kanaat oluşturabilmesi; onun sadece tecrübeye dayanan salt değerlendirmelerini içerdiği gibi, iç denetim biriminin ürettiği bilgilerin tutarlılığını da test edebilir. Böylelikle daha sağlam mesleki yargılara ulaşabilme olanağı sağlayabilir. İç kontrol yapısının işlerliğinin gözetimi üst yönetimin yetkisinde olduğu unutulmamalıdır, bu yönde üst yönetime katkı sağlayarak hem denetim kalitesine ve hem de risk yönetimine etkin bir boyut kazandırabileceği düşünülebilir.

Standartlara göre; denetçi, işletmenin iç kontrolü dâhil, işletme ve çevresini tanımak amacıyla BDS 315 tarafından zorunlu kılınan risk değerlendirme prosedürlerini uygularken ve ilgili çalışmaları gerçekleştirirken, hile kaynaklı "önemli yanlışlık” risklerinin belirlenmesinde kullanacağ prosedürleri uygulaması gerektiğine işaret edilmiştir. Atıfta bulunulan ilgili paragraflara göz attığımızda denetçinin finansal raporlamayla ilgili bilgi sistemi ve iletişim kanallarına, üst yönetim kademesi ve sorumlu olanlarla olan iletişimler ve iç kontrol faaliyet hakkında kanaat oluşturmasına yönelik inceleme faaliyetleriyle ilgili bilgiler verdiğini gözlemleyebiliyoruz.

Yine başka bir standartta iç denetim fonksiyonun varlığının ilgili işletmelerde denetçinin, işletmeyi etkileyen gerçekleşmiş, şüphelenilen veya iddia edilen herhangi bir hile hakkında bilgilerinin olup olmadığını belirlemek ve hile riskleri hakkında görüşlerini almak amacıyla iç denetim fonksiyonunda yer alan uygun kişileri sorgulaması gerektiğini istemektedir. Çünkü burada denetçinin edineceği bilgiler neticesinde mesleki şüphecilik düzeyi ile işletmeye ilişkin genel kanaatlerinin paralel bir durum arz ettiği, bir tutarlılık düzeyi kurduğu söyleyebiliriz. Çünkü iç denetimin sorgulanması denetçinin mesleki yargısının olgunlaşmasını kolaylaştıracak etkileri olduğu düşünülebilir. Kurumsal yönetimin şeffaflık ilkesiyle ilişkilendirebiliriz. (240/ Bağımsız Denetim Standardı)

Bir süreç olarak "kurumsallaşma" kavramına işletmenin tüm taraflarının bakış açıları ve yaklaşımları farklılık göstermektedir. Yönetim kademelerinde, departmandan departmana, şirket ortakları ve diğer paydaşlar açısından kurumsallaşma anlayışları farklılıklar göstermektedir. Her birinin kurumsallaşma sürecinden temel beklentileri ve geliştirdikleri tanımlamaları açısından farklı anlayışlar barındırdığı görülmektedir.

Başka bir standartta sorumlulukların nasıl üleştirileceği ele alınmış ele alınmış ve yukarıda belirttiğimiz hususları destekleyici önermelere yer verilmiştir. Finansal raporlamaya ilişkin sorumlulukların yönetim ve üst yönetimden sorumlu olanlar arasında nasıl paylaşıldığg; işletmenin yapısı ve kaynakları, ilgili mevzuat ile söz konusu kişilerin işletme içindeki 
görevlerine bağlı olarak farklılık gösterir. Genellikle yönetim icradan, üst yönetimden sorumlu olanlar ise yönetimin gözetiminden sorumludur. Bazı durumlarda üst yönetimden sorumlu olanlar finansal tabloların onaylanmasına veya işletmenin finansal raporlamaya ilişkin iç kontrolün izlenmesine yönelik sorumluluğa sahip olabilir veya bu sorumluluğu üstlenebilir. Büyük veya halka açık işletmelerde üst yönetimden sorumlu olanların denetim komitesi gibi bir alt grubu, belirli gözetim sorumluluklarıyla görevlendirilmiş olabilir. (210/Bağımsız Denetim Standard1)

FSB (Financial Stability Board) sağlam mali sistemler için 12 kilit standart öngörmektedir. Ülke koşullarına bağlı olarak öncelikli uygulanılması gerektiği yargısına ulaşılmış ve sağlam mali sistemler için anahtar olarak görülen standartları geniş politika alanları adı altında FSB tarafından belirlenmiştir. Bu standartlar genel olarak ülkelerin sağlam mali sistemleri için minimum karşılanmasını istediği gereksinimleri açıklamakla birlikte bu gereksinimlerin üzerinde teşvik edilen en iyi uygulamaları kapsamaktadır. Bu tavsiye edilen on iki standarttan biri kurumsal yönetim ilkeleridir ve bir diğeri de uluslararası denetim standartlarıdir.

\subsection{Kurumsal Yönetim Süreçlerinin Raporlama Standartları ile İlişkisi}

Kurumlarda bilgilendirmeye yönelik veriler ve veri tabanı sistemleri önemli birer kaynaktır. İnternet teknolojilerinin hızla gelişmesiyle birlikte işletmelerde gerekli gereksiz veri yığınları oluşmaya başlamıştır. Kontrol edilemeyen boyutlara oluşan verilerin bilgiye dönüştürülmesi ve bilgi yönetiminin sürdürebilirliği raporlama tekniğini gerekli kılmaktadır. Günümüzde teknik olarak bilginin depolanması, filtrelenmesi, analiz edilmesi ve tekrardan izlenmek üzere paylaşımı bilgi çağının gerektirdiği koşullarla ilişkilidir. $\mathrm{Bu}$ koşulların güncelliği ve güvenliği de son derece önem taşımaktadır.

Denetim standartlarının üçüncü kısmını oluşturan raporlama standartları denetim sonucunun yazıyla bildirilmesine ilişkin standartlarını kapsamaktadır. Raporlama standartları denetim raporunun yapısı, hazırlanması ve uygunluğuna yönelik ilkeleri açıklamaktadır. Finansal bilgi kullanıcıları açısından finansal tablolarla ilgili mesleki inceleme yaptığına dair yegâne kanıt niteliğindedir. Denetim sonucunda denetçinin finansal tablolar hakkında görüş oluşturması onun denetim sorumluluğu ile ilgilidir. Bu standart denetçinin mesleki tutarlı̆̆ına katk1 sağlamaktadır. Denetçinin mesleki yargısı, verdiği görüşü raporun şekli ve içeriğinin etki düzeyi ile ilişkilidir. Böylelikle küresel piyasalarda anlaşılabilirlik seviyesini güçlendirmekte ve güvenirliliğini artırmaktadır.

Raporlar herhangi bir konu ya da sorun üzerine yapılan inceleme ile ilgili durumu ve sonucu belirtmek üzere yazılan yazılardır. Genel hatları ile raporlamayı iç raporlama ve dış raporlama olarak iki şekilde sınıflandırmak mümkündür. İç raporların temel amacı; kurum çalışanlarını bilgilendirmek, kurumun iç ve dış çevresi arasındaki gelişmelerden onları haberdar etmektir. Dış raporlar ise tüm kurum paydaşlarını ve çevrelerini ekonomik kaynaklı gelişmeler konusunda bilgilendirmeyi amaç edinmektedir. Raporlar kurumların kısa ve uzun vadeli iletişim stratejileriyle ilişkili olmakla beraber yönetimin daha kolay, etkin ve hızlı haberleşme ve izleme aracıdır.

Finansal raporlamanın nasıl ve ne şekilde yapılacağına dair yol gösterici iki unsur vardır. Bunlardan biri kavramsal çerçevedir. İşletme dışı bilgi kullanıcıları için hazırlanan 
finansal tabloların hazırlanması ve sunulmasına yönelik usul ve esasları belirtmektedir. Diğer bir önemli unsurda UFRS (Uluslararası Finansal Raporlama Standartları) ve buna uygun olarak Resmi Gazetede yayımlanan Türkiye Muhasebe Standartlarıdır. Bu standartların en temel özelliği kural bazlı değil ilke bazlı oluşudur. UFRS (Uluslararası Finansal Raporlama Standartları) denetim standartlarının ve denetimin değeri kabul edilen "makul güvence" kavramının anlaşılabilirlik düzeyini pekiştirmektedir. Denetim çalışma alanı standartlarına esas teşkil edecek güvenilir ölçme ve değerlendirme işlemlerinin temel dayanağıdır.

Bağımsız denetim standartları, denetçi raporunda tutarlılığı teşvik eder. Denetçi raporunda tutarlılık; BDS'lere uygun olarak yürütülen bir denetim söz konusu olduğunda, uluslararası kabul görmüş standartlar uyarınca yürütülmüş olan bu denetimleri daha kolay belirlenebilir hâle getirerek, küresel piyasalardaki güvenilirliği artırır. (700/ Bağımsız Denetim Standardı)

Kurumsal raporlar, finansal ve finansal olmayan konuları kapsadığı gibi, araștırma ve inceleme sonucunda elde edilen ihtiyaca uygun bilgilerin karşılaştırılabilir biçimde ve anlaşılabilir bir değerlendirmeyle ilgililere zamanında sunulduğu yazılardır. Yöneticiler işletme ile ilgili kararlar alırken finansal bilgilerin yanı sıra, şirketin pazar payı, entelektüel sermayesi, müşteri memnuniyeti, markası ve insan kaynakları karar verme aşamasında değerleme ölçüsü olabilmektedir.

Kurumsal raporların bazı niteliksel yönleri bulunmaktadır:

- $\quad$ Özel veya kamu adına finansal olmayan raporlamaları da kapsamaktadır,

- $\quad$ Kapsamlı ve güvenilir yönetim raporlaması sağlar, olanağı sağlar,

- Dış raporlamaların ve bilgilendirmeleri şeffaflık yönünden değerlendirilme

- $\quad$ Şirket değerinin en iyi ve gerçekçi şekilde yansıtılmasına yöneliktir, sağlar.

Dış raporlama ve bilgilendirmelerin en iyi uygulamalarla karşılaştırılabilirliğini

Yetkiler kurum adına yöneticiye tanımlanan görev alanlarını ifade etmektedir. Yetki ve yetkilendirmeler yönetim faaliyetlerinin ifasının bir ön oluşumudur. Kurumların tüm yönetim kademelerinde işlemlerin dengeli yönetilebilmesi iyi kurumsal yönetim uygulamalarına bağlıdır. Kötü ve otoriter yönetim yapılarında karşılaşılan en temel sorun güç ve gücün dağılımına bağlı olarak oluşan yetki gasplarıdır. Yetkilerin kötüye kullanılması olarak da tanımlayabileceğimiz bu durumlar hesap vermekten kaçınan ve sorumluluk almayan bir yönetim anlayışını taşır. Aynı zamanda bu tür yönetim yapılarının en temel özelliği güce dayalı üstünlük alanları ile dikte edilmiş hiyerarşinin egemen olmasıdır. Adil ve şeffaf olmayan bilgi yönetimleri suiistimal ve hileli olayların oluşumuna zemin hazırlayabilmektedir.

Bazı durumlarda mevzuat; ilgili dipnotlar da dâhil olmak üzere, finansal tabloları oluşturan bütün tabloların hazırlandığına dair kararın verilmesinden sorumlu olan kişi veya organları (örneğin yöneticiler) ve gerekli onay sürecini belirler. Bu tür durumlarda, finansal tablolara ilişkin denetçi raporuna tarih verilmeden önce, söz konusu onaylamanın yapıldığına ilişkin kanıt elde edilir. Bazı durumlarda ise, onay süreci mevzuat tarafından düzenlenmez. 
Böyle durumlarda, ilgili dipnotları dâhil olmak üzere finansal tabloları oluşturan bütün tabloların hazırlandığına dair kararı verme yetkisine sahip kişi veya organların belirlenmesi amacıyla, işletmenin -yönetim ve üst yönetim yapıları göz önünde bulundurularak- finansal tabloların hazırlanmasında ve bu tablolara son hâlinin verilmesinde uyguladığı prosedürler dikkate alınır. Bazı durumlarda mevzuat, finansal tabloların raporlanması sürecinde denetimin tamamlanmasının beklendiği tarihi belirtir. (700/Bağımsız Denetim Standardı)

2008 krizi bir çeşit kurumsal yönetim krizidir. Zira kriz öncesi şirketlerin risklerini yeterince şeffaf raporlamamaları, teşvik sistemlerine dayanan üst yönetim ücret politikalarının yaygın olarak uygulanması, şeffaf olamayan türev araçlar, şirket yönetim kurullarının etkin gözetim ve denetim faaliyetlerini yerine getirmemeleri, krizin oluşmasında etken olan faktörlerden bir kaçıdır (Ertaş, 2016: ).

\section{SONUÇ}

İşletmelerin denetim yapısı ve içeriği kurumsal yönetimin uygulanması ve geliştirilmesine katkı sunar. Denetim her bir işlemin sağlıklı yürütülmesi için gereklidir. Sağlıklı işlemler, sağlıklı işletmeleri meydana getirir. Denetim kültürüne sahip işletmelerde kurum içi etkileşim düzeyinin yüksek olduğunu ve bu sayede sistemin şeffaf, sorumlu, adil ve hesap verilebilir şekilde yürütüldüğünü söyleyebiliriz. Bilgi üretim ve paylaşım yetenekleri en üst düzeyde olan kurumların sahip olduğu bir özellik güçlü iç denetim yapılarına sahip olmalarıdır.

Son yüzyılda kurumsal yönetim alanında yapılan iyileştirmelerin temelinde sık karşılaşılan şirket iflaslarının olduğunu belirtebiliriz. Sarban Oxley, Arthur Andersen ve en son 2008 yılında yaşanan ekonomik skandallar kötü yönetim uygulamalarından kaynaklanmaktadır. Kurumsal yönetim iyi denetim uygulamaları sayesinde mali krizleri önleme veya olumsuz etkilerini azaltma gibi bir fonksiyona sahiptir.

Bir kurumda temelde iki tür bilgi vardır. Birincisi kişilerin bilgi, birikim, tecrübe ve yeteneklerinin toplamından oluşan insanın kendisinde saklı bulunan örtük bilgi; ikincisi ise yazılı ve kayıtlı olarak çeşitli bilgi kayıt ortamlarında bulunan açık bilgidir (Zaim, 2005:200). Kurumsal yönetim açık bilgi kaynaklarıyla ilgilenmektedir. Kurumsal bilgi kaynaklarının tutarlı, anlaşılabilir, karşılaştırılabilir ve doğrulanabilir yönde olmasını arzular. Denetçinin takınacağı mesleki şüphecilik tavrı kurum içindeki örtük bilgi kaynaklarının açık bilgiye dönüştürme çabalarını kapsamaktadır. Kurumsal yönetimin temel alanı çerçevesinde yer alan şeffaflık ilkesi ile denetçinin takınacağı mesleki şüphecilik tavrının hem esasen hem de usulen ilişkili bir yönünü olduğunu söyleyebiliriz. Bu yönüyle kurumsal yönetim ve denetim süreçleri açısından mesleki şüphecilik önemli bir köprü görevi üstlenmektedir. Mesleki şüphecilik kavramı sadece denetim standartları içerisinde adı geçen bir olgu olarak dikkate alınmaktadır. Yeni bir kavram olmasından dolayı denetim literatüründe nasıl, ne yönde ve ne şekilde kullanılacağına dair teorik açıklamalar yeterli düzeyde değildir. Sadece mesleki şüphecilik düzeyinin denetçi tarafından aşırıya kaçtığında paranoyaya dönüşebileceğine dair görüşler ile sınırlıdır. Literatürde sadece denetim faaliyetlerindeki rolü ele alınmış, kurumsal yönetim parametreleri arasındaki rolü ihmal edilmiştir. Oysaki mesleki şüphecilik kurumsal risk yönetiminin en etkin dinamikleri arasında yerini almalıdır. 
Yönetim kademelerinin sorumluluk alanlarının ve faaliyetlerinin hesap verebilir, şeffaf, sorumlu ve adil bir düzeyde yürütülmesi denetim olgusunu içselleştirebilme becerileriyle ilişkilidir. İyi kurumsal yönetim uygulamalarının işletmelerden bir temel beklentisi de denetimin bir kurum kültürü haline getirmeyi başarabilmeleridir. Entelektüel kurumsal birikimin işlevsel yansıması, güvenilir bilgi temelinde teyit edilebilen şeffaf ve adil bilgilerin üretilmesi ve paylaşılması ile mümkündür.

İşletmelerin, bilgi yönetim süreçlerinde menfaat sahiplerine yönelik politika geliştirmeleri, menfaat sahiplerinin işletme yönetimine katılmalarının desteklenmesi ve oluşturulacak yönetim komitelerinin etkinliği önem taşımaktadır. Günümüzde işletmelerin hakim ortaklar dışında, diğer menfaat sahipleri olan devlet, küçük hissedarlar, kredi verenler için de sürdürülebilir olması beklenmektedir. İşletmelerin birleşmesinden oluşan genel mali sistemin sağlıklı yürümesi için tüm menfaat sahiplerinin çıkarlarının korunması esastır. Bu da ancak hesap verebilir, sorumlu, şeffaf ve adil yönetimle mümkündür. Uluslar arası denetim standartları bu şartların sağlanmasını düzenleyen en önemli yapı taşıdır. Kurumsal yönetimin temel amacı sağlıklı mali yapı oluşturulmasıdır.

\section{KAYNAKLAR}

Aktan, C.C. (2006), Organizasyon ve Yönetim Bilimleri Dergisi Cilt 5, Sayı 1, ss.150-182 2013 ISSN: 1309 -8039 (Online) http://dergipark.gov.tr/download/article-file/333088

Asian Passific Economic Corporation Forum, (2003).

Emergin Markets Committee, (1998), s.72, Aktaran: Demirbaş, M. ve Uyar, S. (2006), “Kurumsal Yönetim İlkeleri ve Denetim Komitesi”, s.31, İstanbul.

G20 Bakanlar ve Merkez Bankası Başkanları Toplantısı, 4-5 Eylül (2015), Ankara. http://www.oecd.org/daf/ca/Corporate-Governance-Principles-

TUR.pdf,(E.T:05.01.2016)

G20/OECD Kurumsal Yönetim İlkeleri: https://www.oecd.org/daf/ca/Corporate-GovernancePrinciples-TUR.pdf

(E.T. 20.04.2016)

(http://www.oecd.org/corporate/ca/corporategovernanceprinciples/31557724.pdf, 2004).

Gürbüz, A. O. (2005), "Kurumsal Yönetim: Ülkemizdeki Düzeyine İlişkin Değerlendirmeler", Antalya. 7. Muhasebe Denetim Sempozyumu, ss. 1-19, 20-24 Nisan 2005, http://www.ismmmo.org.tr ,( E.T:10.09.2015)

Güredin, E. (2010), “Denetim ve güvence hizmetleri”, Türkmen Kitabevi 13. Bask1, İstanbul.

Hermanson, R.D. ve Rittenberg, E. L. (2003), "Internal Audit and Organizational Governance”, The Institute of Internal Auditors Research Foundation.

Karpuzoğlu, E. (2003), "Büyüyen ve Gelişen Aile Şirketlerinde Kurumsallaşma”, Hayat Yayınları, 2. Bask1, İstanbul.

Koçel, T. (2003), “İşletme Yöneticiliği”, Beta Yayınları No. 1382/120, İstanbul. 
OECD Principles of Corporate Governance , (2004), http://www.oecd.org/corporate/ca/corporategovernanceprinciples/31557724.pdf (E.T:11.09.2015)

Şavlı, T. (2012), "Uluslararası Denetim Standartları Kapsamında Bağımsız Denetim Süreci”, http://archive.ismmmo.org.tr/docs/Sempozyum/10/TR/TUBASAVLI.pdf (E.T:14.06.2016)

Türedi, H. (2013), “KGK Denetim Seminer Notları”, İstanbul.

Ulukan, C. (2005), "Girişimcilerin ve Profesyonel Yöneticilerin Kurumsallaşma Perspektifi", Anadolu Üniversitesi Sosyal Bilimler Dergisi, Eskişehir.

Ertaş V. (2016), "IX. Kurumsal Yönetim Zirvesi Açılış Konuşması", http://www.spk.gov.tr/duyurugoster.aspx?aid=20160114\&subid=1\&ct=f E.T: 01.05.2016.

Zaim, H. (2005), "Bilginin Artan Önemi ve Bilgi Yönetimi”, İşaret Yayınları, İstanbul.

Zehnder, E. (2000), “Board of Directors Global Study”. 